\title{
Revealing the Causes of the Loss of the Islamic Troops in the Battle of Uhud
}

\author{
$1^{\text {st }}$ Azis Arifin ${ }^{1}, 2^{\text {nd }}$ Hamka Hasan $^{2}, 3^{\text {rd }}$ Imam Subchi $^{3}$ \\ \{azis.arifin20@mhs.uinjkt.ac.id ${ }^{1}$, hamkahasan@uinjkt.ac.id², imam.subchi@uinjkt.ac.id ${ }^{3}$ \} \\ UIN Syarif Hidayatullah Jakarta ${ }^{1,2,3}$
}

\begin{abstract}
The imbalance in the quantity and composition of the two armies is not the cause of the defeat of the Muslim troops in Uhud war. As evidence, the battle of Badr was won by a landslide by the Islamic forces even though their numbers were far less than the enemy. This paper aims to reveal the cause of the defeat of the Islamic troops in the Uhud war. This research is qualitative using a historical approach, and the existing data is presented in a descriptive analytical manner. The results of this study reveal that the cause of the defeat of the Muslims in the battle of Uhud was caused by at least two factors, firstly the ignorance of the archers at the command of the Prophet not to descend the hill, secondly the effectiveness of the Quraysh's ruse by maneuvering the screams of the killing of the Prophet.
\end{abstract}

Keywords: Uhud War; Islamic troops; Quraysh troops, the cause of the defeat of the Muslims.

\section{Introduction}

During his life, the Prophet had participated in many wars. War in the history of Islamic civilization is something that can be considered normal. In general, war is an indicator of social turmoil in human civilization. War in the history of Islam itself is an effort to construct the development of the religious civilization. Studying history, including political history or more familiarly referred to as old stories, including wars, can provide a deeper perspective on historical studies[1]. The wars that occurred at that time seemed to be part of self-defense in realizing the existence of peace. In another sense, these wars were not part of the way the Prophet Muhammad spread Islam. In general, wars are divided into two parts, namely wars that the Messenger of Allah participated in and wars that were not followed by the Prophet.

In naming the two conditions, it seems necessary to distinguish. The war that the Prophet followed was named by the term ghazwa. Every war in which the Prophet was involved in it actually always ended in victory, except for only one, namely the battle of U'ud. At the same time the war that the Prophet was not involved in is called a sariyah. The core, both ghazwa and sariyah, were both forms of defense of Muslims against the attacks of the polytheists at that time[2].

The war of Uhud as the only ghazwa that ended in defeat was normatively legitimized by the Messenger of Allah. This is given the existence of several provisions of the law of war when the Prophet was still alive. First, it is not permitted by the Prophet Muhammad. For example, when da'wah was still being carried out clandestinely in Mecca, the Muslims at that time asked the Apostle to fight against the Quraysh, but he did not grant it. He only asked the 
Muslims to be patient and emphasized that he did not order them to fight. Second, the Messenger of Allah allowed it because the Qur'an ordered it. This is as stated in QS. Al-Hajj: 39. Third, it is obligatory to fight because it is being fought, as stated in the QS. Al-Baqarah: 190. Fourth, it is obligatory to fight the polytheists in general, as stated in the QS. Al-Taubah: $36[2]$.

The division of the law is also based on the level. This can be seen based on the gradation of permits, from those that are not permitted at all to those that are absolutely mandatory. However, presumably for the last section it needs to be reviewed. The reason is, the obligation to fight the polytheists in general as stated in the QS. Al-Taubah: 36 only if they fight Muslims in general anyway. In other words, if they do not fight the Muslims in a thorough manner, then there is no obligation at all for the Muslims to fight them.

As a war that falls into the terrible category, the Uhud war leaves several issues that are still considered complicated. The reason is, the war which involved at least 3,700 soldiers[3] was finally won by the Quraysh. Unfortunately, this is the first time that Muslims have experienced defeat after at least two wars, namely the Battle of Badr and the Battle of Bani Qainuqā', one of which has the same characteristics as the Uhud war.

Efforts to uncover the causes of the defeat of Muslims in the U'ud war seem to be important things to be investigated in this article. The reason is that the imbalance in the quantity and composition of the two armies is not the cause of the defeat of the Muslim troops in this war. As evidence, the Battle of Badr, which was the first war after the Prophet's migration to Medina, was won by the Islamic troops in a landslide even though their numbers were far less than the enemy. Based on this similarity, the defeat of the Muslims in the U'ud war was judged not to be due to the disequilibrium of the quantity of troops.

The discussion about the Uhud war has actually been studied by many scholars. Nicolas Habibi, et al, in his article entitled Refleksi Kepemimpinan Dan Strategi Perang Nabi Muhammad (Studi Kontekstual Legitimasi Sejarah Perang Uhud). This study describes how the leadership of the Prophet before, during and after the Uhud war. This study also confirms that the Prophet was an astute leader in managing war strategies[4]. Furthermore, Samsul Hakim examined the axiology of the value of moral education contained in the events of the Uhud war. In his writing entitled Kajian Aksiologi Nilai-nilai Pendidikan Akhlak dalam Sejarah Perang Uhud, Hakim emphasized that a comprehensive understanding of the events of the Uhud war actually provided an opportunity to be able to know something that was written or implied. Armed with a philosophical approach and technical content analysis analysis, Hakim found the results that the Uhud war incident provided lessons on moral values that should be used as a reference for a Muslim in living his life[5]. Next, Hasbi Ash Shidqi, et al, under the title Nilai-nilai Pendidikan dalam Perang Uhud, they explained how the U'ud incident had provided many good role models for Muslims to rely on. Some of the values of moral education presented by Shidqi et al include love for the Prophet, patience and the permissibility of arrogance in war. Shidqi et al. tried to uncover why the Prophet did not ask for help from his non-Muslim Muslim colleagues to join the war against the Meccan Quraysh as part of the moral education taught by the Prophet[6].

Several studies have been carried out above on principle relating to the Uhud event. However, none of them discussed the causes of the decline of the Islamic troops in this war. Some of the research presented discusses the leadership, education, morals and attack tactics which are reflected in the Uhud war. Thus, the author tries to enter another gap that is considered empty in order to complete the scientific treasures, especially in the field of prophetic history. 


\section{Methodology}

The method used in this study is qualitative using a historical approach. The historical approach in this study is intended to determine the whole cause of the defeat of the Islamic troops led by the Prophet himself in the Uhud war. The primary source used is Sīrah al-Nabiy 'alaih al-Șalāh wa Salām by Ab̄̄ Muḥammad 'Abd al-Malik bin Hisyām. While the secondary source is Ghazawāt al-Rasv̄l allallāh 'alaih wa Sallam Durōs wa 'Ibar wa Fawāid by 'Alī Muhammad al-Ṣalābī, journals and other relevant sources.

\section{Result and Discussion}

\subsection{The Psychology of the Quraysh on the Bitter Fact of Losing at Badr}

After experiencing defeat in the battle of Badr, the Quraysh harbored great anger against the Muslims. His desire for revenge was so great that they tried to hold back as much as possible so as not to shed tears because of the large number of their troops who 'lost' in the war[3]. Perhaps they were trying to come to terms with what had happened to them. However, this strong feeling is not to be accepted completely but as a composition of their square off in taking revenge against the Muslims.

It seems that what they are trying to do is actually successful, because the Muslims do not see the look of sadness on their faces. In addition to their success in hiding their sadness, this was also due to the fact that the intervals between the Islamic and Quraysh troops were so far apart, as a result it was very difficult to obtain real testimonies[3]. Their sadness and anger seemed real, among their dignitaries who were killed in the war was Ab̄ Jahl, a figure who was clearly their role model[3].

The Battle of Badr was actually not only the cause of the Uhud war. Historians note, the Battle of Badr was also the cause of the Bani Qainuqā' war. Banu Qainuqā' carried out acts of intimidation against the Muslims in Medina. This was done as a form of their resistance to the feelings of fear that always haunted themselves after the Islamic troops won the battle at the Battle of Badr against the Quraysh which took place about twenty-five days earlier, in the month of Shawwal, the second year of Hijriyah[7]. This attitude seems excessive, considering that the Prophet himself would not attack them as long as they did not betray the agreement contained in the previous agreement sheet. Instead the Prophet regretted their actions and hoped that they would not betray him. The Messenger of Allah hoped that the city of Medina would remain safe and peaceful in diversity[7].

But how else, Bani Qainuqā 'arrogantly challenged the war against the Messenger of Allah and the Muslims. They said that the Muslims had fought an army that did not understand the war strategy, so it fitted that the Muslim army would win. They also said that if the Muslims had fought against them, the story would have been different. Hearing this challenge, finally it was decided not to fight them by killing him but to expel them from Medina as a revenge for the betrayal they had committed[8].

\subsection{Social Politics Becomes the Strongest Factor in the Uhud War}

Among the various factors that caused the Uhud war, social and political reasons were strong reasons why the war was raging. When the Battle of Badr was over, the Quraysh 
revealed something to Abū Sufyān and the people who were traveling "O Quraysh, indeed Muhammad has shackled you, he has also killed your chosen people"[9]. The great defeat in the Battle of Badr, the killing of the Quraysh leaders, the feeling of shame and humiliation for their defeat made them earnest in clearing their good name and dignity by collecting contributions among them to fight the Messenger of Allah[2].

Abv Ja'far as conveyed by al-Tabarī also said the same thing. The battle of Badr was carried out solely to avenge the Quraysh against the Muslims for the defeat that embarrassed them at the Battle of Badr. This revenge mission is crystallized in several stages, starting from deliberation, gathering budgets and conducting raids[10]. The money collected from these contributions is approximately 50,000 dinars. That amount of money will be allocated to pay soldiers and complete the logistics of war needs[11].

After the defeat at the Battle of Badr, the sovereignty of the Quraysh of Mecca was completely destroyed. The Quraysh's central power was also shaken because the tribal leaders did not behave as they normally would. Thus, like it or not, they should be given appreciation for their persistence in defending the Quraysh in the battle of Badr[2].

But their defeat at Badr also had a devastating impact on the people of the interior of Medina and the Quraysh themselves. If previously they underestimated the strength of the Muslims, then the bitter fact of their defeat in the war made them realize that the stagnation of the Muslims could not be underestimated. Of course, this great victory was grateful for and used as capital for the development of Muslim strength in Medina to repel enemy attacks in the future[12]. In addition, thanks to this victory, the Quraysh in Mecca realized that Islam would expand and this would make the existence of their belief eroded over time[12].

\subsection{The Strategy Debate in Dealing with the Quraysh Troops}

The Messenger of Allah who knew the enemy's current position from his intelligence Namely Anas, Hubab ibn Munzīr and Munis. This Hubab is one of the companions who also fought with the Prophet at Badr-[13] quickly invited his companions to discuss how to deal with their attack, whether to wait for their attack in Medina or follow their troops to where they are now. The final result of the deliberation was the second option, which was to approach the enemy to 'Unain[11].

The same thing was conveyed by Ibn Hisham who quoted Ibn Ishaq's opinion. According to him, both options are based on their respective arguments. Waiting for the enemy to come to Medina and then attack them in order to be cornered by the citizens of the city is a strategic option that actually makes sense. This is the option of 'Abdullāh ibn Ubay, the Messenger of Allah also opted for this strategy. The Messenger of Allah wanted the war not to be carried out in the open field. However, one of the friends mentioned another option, he thought that it would be better if we held back enemy attacks on the battlefield openly. This is to dispel the impression that Muslims are afraid of them and their belief in Allah's help is so high[14].

This option was spontaneously cut off by 'Abdullāh ibn Ubay, he asked the Apostle to exercise his option, waiting in Medina. He threatened that he would not join the war if the Messenger of Allah did not exercise his option. Then he repeated the technical explanation of how the options were applied. The two parties who offered their respective options argued and it seemed that the Prophet did not like it. So that the proponent of the second option feels guilty about it. But in the end, the second option was chosen as the initial strategy of the war[9]. 


\subsection{Two Causes of the Defeat of the Muslim Troops in the Battle of Uhud}

Basically, the defeat of the Muslims in this war was caused by themselves. This is as enshrined in QS. Ali Imrān: 165 as follows:

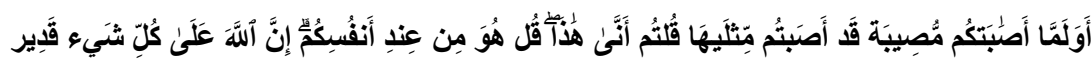

Translation: And why when calamity befalls you (in the battle of Uhud), even though you have inflicted a double defeat on your enemies (in the battle of Badr), you say: "Where did this (defeat) come from?" Say: "It's from (your fault) yourself". Verily Allah has power over all things. (Surat Ali Imrān: 165).

Ahmad bin Muṣtafā al-Marāghī revealed that what is meant by 'disaster' in verse is the defeat of the Islamic troops from the polytheists in the Uhud war. This verse, according to alMarāghi, is a form of God's firm answer to the defeat received by the Islamic troops. Allah emphasized that they should not be surprised, because the defeat was caused by themselves by the betrayal they committed. In this case too, why did they forget the grace of Allah for the victory at Badr some time ago? They don't bring it up and instead wonder something they actually know[15].

As already stated, the archers are the main bastion of defense in this war. The Apostle really gave a big mandate to them not to leave the hill at all. Because, only then, all the troops under the hill will be protected. As a master strategist, it seems that the Messenger of Allah knew very well the consequences if the archer troops lifted their feet from the hill. However, the archers forgot their master's orders. On the other hand, the Quraysh's ploy to outwit the concentration of Muslim infantry was very effective. Hearing the screams of the Prophet's death, most of the Muslim soldiers suddenly felt helpless. This situation was then put to good use by the enemy to repulse the Islamic troops.

\subsubsection{Disregarding the Prophet's Order: Archers Leave the Hill}

Seeing the movement of the enemy back and forth, the archers who were ordered by the Apostle not to go down the hill suppressed the prohibition. They were tempted by the enemy's supplies and decided to take it down. 'Abdullāh bin Jubair as their leader reminded them to stick to the message conveyed by the Prophet[16]. But they ignored the leader's words and said that they had to go down the hill in order to get ghanimah[16], so that out of a total of 50 archers, 37 of them were desperate to go down the hill because they were tempted by the clothes and valuable supplies left by the enemy[14].

The remaining thirteen were still loyal to the Prophet's order to remain on the hill, among them was the leader himself, Abdullāh bin Jubair. Seeing that the majority of the archers were not on the hill, the Quraysh army turned against the Muslims and hit all the archers who were still on the hill without a single one left. They also attacked the greedy archers who were still busy with their intentions, gathering the enemy's ghanimah[11].

\subsubsection{The Trick of the Quraysh}

In such tense conditions, someone from the Quraysh army shouted very loudly "Muhammad has been killed, Muhammad has been killed"-even though the scream was just a trick meant to trick the Islamic troops into losing their focus and losing their will to fight. It was the scream of a cursed devil-[11]. Hearing the shout, Mușab ibn 'Umair who 
became the flag bearer of the Islamic troops and most of the Muslim soldiers suddenly felt helpless[14], including Hamzah bin 'Abd al-Mutālib. And at that moment, he was killed by the spear that Wahsh threw. The incident where amzah's stomach was unsheathed was right after he had a one-on-one duel with Siba 'bin Abdul Uzza which killed him. This accurate spear throw had completely rendered him defenseless. Wahsyī also rushed to retrieve his spear and made sure that amzah had been killed by his spear[17][11][14].

Wahsyi the spear wielder approached and approached Hamzah's body. After his death was confirmed, Hind then approached and sadistically he opened his stomach and ate his liver[14]. In fact, the Islamic army had begun to doubt when the archer army was gone. Then their psyche was also tested with the issue of the murder of the Apostle. This clearly made matters worse. Some of them said, "Then what is the meaning of our life if the Messenger of Allah is killed?" Anas ibn Naḍar who heard the moaning then said "then what is the use of your life after the Messenger of Allah? Then he continued with the words "O Allah, I am free from those who defected and said such nonsense" then he again raised his sword and continued to fight against the Quraysh until he died[18].

Rasulullah then took the flag and proved that he was fine. Then he was showered with arrows, swords and spears by the enemy. How they wanted to kill the Prophet. The Apostle bravely resisted all these attacks, still lunging and not retreating even if it was only a step. Although he had to lose one lower tooth, the metal armor on his head broke and suffered a cut on his head from the attacks[14][11]. Seeing the Prophet injured, Fâtimah rushed to him. He was assisted by 'Ali trying to treat the Apostle. But it was only in vain because the blood flowing from the wound of the Apostle did not stop. Fâtimah tried her luck by taking some straw and burning it. After that, affixed the ashes of straw on the place of the wound of the Prophet[18].

The companions of Anșār who at that time were near the Prophet had to die because of it. As for 'Usmān bin Mughīrah, who at that time intended to attack the Apostle with a spear, had to die a ridiculous death by āris̀'s spear. Likewise Ubay bin Khalaf, when he tried to spear the Prophet, he swiftly preceded him. After this incident, the Quraysh army withdrew. 'Alī bin Abī ālib and alhah approached the Apostle then they rushed to the bottom of the foothills of Uhud accompanied by other Muslim troops[11].

After taking care of the fallen soldiers, -he ordered his surviving troops to bury those who died on this battlefield-[14] numbering at least 70 people[15][16], the Prophet returned to Medina on Saturday afternoon. Even though the war of Uhud had ended, the Prophet Muhammad still had several unanswered questions, including about the movement of the Quraysh troops to retreat. He hypothesized that the Quraysh army, which had more troops, seemed too simple to suddenly withdraw and refuse to continue the war. Therefore, the Prophet ordered 'Alī bin Abī âlib to investigate and monitor the movements of the Quraysh troops[19].

Based on this order, 'Al set out to investigate the movements of the Quraysh troops by carrying out disguises. After completing the investigation, 'Ali immediately appeared and reported the results of the investigation to the Prophet that the Quraysh army was heading towards the South. Based on this report, the Prophet felt confident that the Quraysh army would indeed return to Mecca[20]. The tense atmosphere of this war was immortalized by al-Bukhārī in his book, Saḥīh[16]. 


\section{Conclusion}

The Battle of Uhud was a war between the Muslims and the Quraysh. The war that took place in $3 \mathrm{H}$ was won by the Quraysh of Mecca and the Islamic troops had to be willing to swallow the bitter pill for the defeat they had received. The cause of the defeat of the Muslims in this war was at least due to two factors, namely the first ignorance of the archers at the Prophet's command not to descend the hill, secondly the effectiveness of the Quraysh's ruse by maneuvering the screams of the Prophet's death. These two actions seem to be valuable lessons for Muslims around the world, including in Indonesia. Obeying orders and carrying out the leader's command is absolute in the scope of strategy application. Disobedience to the leader's orders is the beginning of damage. The Prophet became a leader who had the capacity and capability that was very worthy to be used as a patron in living the ins and outs of life. Not only as a leader in world affairs, he is also a role model for life in the eternal, the hereafter. What happened to the Muslims in this war was actually a form of warning from Allah SWT to always obey the Messenger of Allah, practice his hadith and be patient with all the trials that befallen. This incident also teaches that everything that looks beautiful in the eyes is not necessarily judged as beautiful by the heart. Likewise, something that is considered profitable, does not necessarily give happiness. The best way to deal with it is to return to the main goal, the goal that is pleasing to Allah SWT.

This research is only limited to the Uhud war. There are still other wars in which the Islamic troops also experienced defeat, of course the cause must also be revealed. In addition, this study only discusses one corner of the problem, while several other broader angles are not touched at all. Therefore, this is a weakness in this study.

The psychology of Islamic troops when they heard the false news of the death of the Prophet in relation to their defeat in the war seemed to need further investigation. This is intended to determine the level of concentration and motivation of a troop when its commander is attacked. By researching these issues, it is hoped that there will be a way to deal with similar incidents so that the troops remain focused on carrying out their mission.

\section{References}

[1] T. Ramadhan, In the Footsteps of the Prophet. New York: Oxford University Press, 2007.

[2] 'Alī Muḥammad Al-Ṣalābī, Ghazawāt al-Rasv̄l Șallallāh 'alaih wa Sallam Durōs wa 'Ibar wa

Fawāid. Kairo: Muassasah Iqra', 2007.

[3] Șafiy al-Raḥmān Al-Mubārakfūrī, al-Rahīq al-Makhtōm Baḥs al-Sìrah al-Nabawiyyah 'alā Șăhibihā Afḍal al-Ṣalāh wa al-Salām. Qatar: Wizārah al-Auqāf wa al-Syu'v̄n al-Islāmiyyah, 2007.

[4] N. Habibi, I. M. Daud, I. Agama, and I. Negeri, "Refleksi Kepemimpinan dan Strategi Perang Nabi Muhammad (Studi Kontekstual Legitimasi Sejarah Perang Uhud)," Ishlah J. Ilmu Ushuluddin, Adab dan Dakwah, vol. 2, no. 2, pp. 203-223, 2020.

[5] S. Hakim, "Kajian Aksiologi Nilai-nilai Pendidikan Akhlak dalam Sejarah Perang Uhud," J. AlAmin; Kaji. Pendidik. dan Sos. Kemasyarakatan, vol. 4, no. 2, pp. 85-103, 2019.

[6] H. A. Shidqi et al., "Nilai - Nilai Pendidikan dalam Perang Uhud," Fikiran Masy., vol. 3, no. 2, pp. 52-80, 2015.

[7] M. bin A. Bāsyimil, Mausv̄'ah al-Ghazawāt al-Kubrā. Mesir: Dār al-Hādī al-Nabawī.

[8] M. H. Haikal, Sejarah Hidup Muhammad, terj. Ali Audah, 5th ed. Jakarta: Pustaka Jaya, 1980.

[9] A. M. 'Abd al-M. bin Hisyām, Sìrah al-Nabiy 'alaih al-Șalāh wa al-Salām. Mesir: Maṭba'ah alKhairiyyah, 1329.

[10] A. J. M. bin J. Al-Ṭabari, Tārīkh al-Umam wa al-Mulv̄k Tārīkh al-Ṭabari. Riyāạ: Bait al-Afkār al-Dauliyyah. 
[11] M. J. ibn A. Al-Raḥmān, Syi'r al-Hisān fĩ Tafāṣ̄ll Maulid Sayyid al-Ins wa al-Jān. Jakarta: Masyrakah ‘Alī Riḍā.

[12] A. K, A Study of Islamic History, Terj. Ghufron A. Mas'adi. Jakarta: PT Grafindo Persada, 1996. [13] A. A. Ridzuan, M. J. H. Kadir, and H. A.-B. Mohamed, "Perang Badar dan Uhud: Satu Analisis Strategi Peperangan dan Pertahanan Nabi Muhammad SAW," 'Ulum Islam. J., vol. 10, pp. 31-51, 2013.

[14] J. A. C. Brown, Muhammad A Very Short Introduction. (New York: Oxford University Press, 2011.

[15] A. bin M. Al-Marāghī, Tafsīr al-Marāghī. Mesir: Syirkah Maktabah wa Maṭba'ah Muștafā alBābīi, 1946.

[16] M. bin I. A. 'Abdillāh Al-Bukhārī, al-Jāmi' al-Ṣaḥ̄hh al-Mukhtaṣar, 3rd ed. Beirut: Dār ibn Kasīir, 1987.

[17] F. Bahri, Sirah Nabawiyah Ibnu Hisyam. Jakarta: Darul Falah, 2000.

[18] M. S. R. Al-Buțī, Fiqh al-Sīrah Ma'a Mujāz Li Tārīkh al-Khilāfah al-Rasyīdah. Damaskus: Dār al-Fikr, 1991.

[19] A.-Ḥāfiz I. Kas̄īr, Al-Fușvil fī Sīrah Rasv̄l. Kuwait: Dār al-Ghirās, 2003.

[20] J. E. Campo, Encyclopedia of Islam. New York: Campo, 2009. 